\title{
O aniquilamento de Cartago e Numância*
}

Breno Battistin Sebastiani**

\section{RESUMO}

A tradição historiográfica, iniciada com Políbio, a respeito da trajetória política de Cipião Emiliano (185-129 a.C.), descreveu-a como marcada pela criação de precedentes institucionais por meio de sucessivos atos de concentração de poder e violência militar. Até hoje a maioria dos historiadores tem interpretado essa tradição como favorável à imagem do comandante romano, a despeito das ressalvas de A. Momigliano. Partindo dessas ressalvas, alguns momentos-chave dessa tradição (a obtençáo de dois consulados e o aniquilamento das cidades de Cartago e Numância por Cipião) mostram também um viés crítico, sobretudo devido ao contraste entre as imagens tópicas do intelectual aberto ao helenismo e do comandante competente embora truculento.

Palavras-chave: Cipião Emiliano; Cartago; Numância; helenismo; violência.

\begin{abstract}
The historiographical tradition originated with Polybius about the political career of Scipio Aemilianus (185-129 B.C.) presented it as marked by the creation of institutional precedents through successive acts of concentration of power and of military violence. Until today, most historians have interpreted this tradition as being favorable to the image of the Roman commander, despite A. Momigliano's reservations. Considering these reservations, some key moments in that tradition (Scipio's reaching of two consulships and the annihilation of Carthage and Numantia) present also a critical bias, particularly because of the contrast between the topic images both of the learned man open to Hellenism and of the competent but truculent commander.
\end{abstract}

Keywords: Scipio Aemilianus; Carthage; Numantia; Hellenism; violence.

Artigo recebido em 18 de janeiro de 2013 e aceito em 18 de fevereiro de 2013.

* Agradeço todas as sugestóes dos pareceristas. As traduçóes são de minha responsabilidade.

** Doutor em história social pela Universidade de São Paulo, professor na Universidade de São Paulo. São Paulo, SP, Brasil.

E-mail: sebastiani@usp.br. 
Remonta a Políbio, direta ou indiretamente, a maioria das informaçóes atualmente disponíveis sobre o filelenismo e a carreira política de Cipião Emiliano, a qual culminou nas destruiçóes de Cartago e Numância. ${ }^{1}$ Os principais autores que se basearam em Políbio para tratar de Cipião Emiliano foram Diodoro, Plutarco e, sobretudo, Apiano. ${ }^{2} \mathrm{O}$ próprio Políbio, que fora perito em táticas e engenhos militares, sugeriu a complementaridade entre o filelenismo e a carreira política do discípulo: ao jovem Cipiáo angustiado por ainda náo corresponder aos ideais ancestrais Políbio teria dito que "não encontraria colaboradores e ajudantes melhores do que eu"; ${ }^{3}$ anos depois, Políbio esteve ao lado de Cipião, como auxiliar técnico, durante a tomada de Cartago, e provavelmente também participou do cerco a Numância.

Qualquer julgamento sobre o significado dessa e de outras sugestôes presentes na obra precisa considerar dois fatores: o fato de que os últimos dez livros das Histórias apresentam indícios que levaram ao menos dois historiadores ${ }^{4}$ a situar sua redação após a morte de Cipião Emiliano, ocorrida em 129 a.C.; e o provável contexto social com que Políbio dialogava enquanto os escrevia. Ao narrar a Terceira Guerra Púnica a partir do livro 36, Políbio não se furtou a expor as opinióes dos gregos sobre política romana em relação a Cartago durante os anos 150-149 a.C., ${ }^{5}$ duas das quais eram denúncias devastadoras contra a crueza e a deslealdade romanas. A. Momigliano avaliou a situaçáo delicada do historiador e sugeriu um sentido para tal iniciativa:

O círculo vicioso devido ao qual nosso entendimento de Políbio depende de nosso entendimento sobre o imperialismo romano e vice-versa se desfaz tão logo apreciamos sua real situação. Ele estava preso ao sistema que tentou descrever. Ele não era livre - no sentido menos metafísico da palavra. Desaprovar Roma era perecer. Mas pelo simples esforço de estudar as causas e consequências de suas vitórias Políbio criou um espaço para si mesmo. Ele nunca aceitou completamente os romanos. Ele desconfiava de sua helenização. ${ }^{6}$

Embora a interpretação de Momigliano tentasse aclarar um problema insolúvel — qual a real opinião de Políbio sobre o massacre de Cartago, isto é, qual sua posição sobre a política externa romana após 150 a.C. de modo geral —, ela abre caminho, também, para outro tipo de investigação sobre a tradição que, derivada majoritariamente das narrativas de Políbio, ${ }^{7}$ costurou os topoi com os quais Cipiáo Emiliano foi apresentado como imagem de comandante competente: ao invés de elogiosa, como parece à primeira vista, quanto de crítica aos atos do comandante se ocultaria sob essa tradição, quando lida em contraste com o contexto em que foi inserida, isto é, com outros passos que reportaram opiniôes não romanas denunciando o emprego da violência como meio de resolução de conflitos externos por parte da potência então dominante? Seriam as declaraçóes de amizade de Políbio, bem como sua presença em Cartago, elementos suficientes para definir como positivo seu juízo sobre os atos do discípulo? O historiador náo parecia à vontade aos olhos de seus compatriotas quando escreveu que acatara uma

${ }^{1}$ Filelenismo de Cipião: Plb.31.23-30; destruição de Cartago: Plb.38.19a-22; destruição de Numância: monografia sobre a Guerra Numantina mencionada por Cícero (AdFam.5.12.2) e atualmente perdida.

${ }^{2}$ Diodoro: livros 31-32; Plutarco: Apotegmas de reis e comandantes, Vida de Emílio Paulo, Vida de Tibério Graco; Apiano: Guerras Púnicas, Guerras na Ibéria.

${ }^{3}$ Plb.31.24.8.

${ }^{4}$ BARONOWSKI, Donald Walter. Polybius and Roman imperialism. Londres: Bristol Classical Press, 2011. p. 4; WALBANK, Frank William. Selected papers. Studies in Greek and Roman history and historiography. Cambridge: Cambridge University Press, 1985. p. 325-330.

${ }^{5}$ Plb.36.9.

${ }^{6}$ MOMIGLIANO, Arnaldo. Sesto contributo alla storia degli studi classici e del mondo antico t. I. Roma: Storia e Letteratura, 1980. p. 85. A resenha “The historian's skin” foi originalmente publicada em 1974.

${ }^{7}$ Rutílio Rufo (t. 1 Peter), legado de Cipião em Numância, também teria escrito uma monografia a respeito. 
primeira ordem de partida para a África "por pensar que devesse obediência aos romanos". ${ }^{8}$ Os topoi empregados para descrever a crueza romana contra Cartago e Numância visariam apenas a valorizar a imagem de bravura e competência de Cipião, ou seriam um recurso habilmente empregado por um aristocrata helênico que, embora dependente e favorecido pelos romanos após 146 a.C., estaria incomodado com a escalada de violência como fator decisivo da política externa romana? Sem que se incorra no anacronismo de sentenciar o passado por critérios que lhe foram desconhecidos, a trajetória política de Cipião Emiliano, que culmina nos excídios de Cartago e Numância, continuará dando margem a investigação focada nesse viés ao menos enquanto houver historiadores dedicando páginas a discutir o motivo das lágrimas do cônsul diante do incêndio de Cartago. ${ }^{9}$ Mais promissoras são as conclusóes de D. Baronowski sobre as reservas mentais de Políbio ante a truculência romana após 146 a.C. ${ }^{10}$

O filelenismo de Cipião Emiliano, ${ }^{11}$ sobretudo em razão dos estudos filosóficos e literários que o acompanharam por toda a vida desde a adolescência, e por sua intrínseca natureza de fenômeno secundário, complementar à formação tradicional de um aristocrata romano do século II a.C., realça a necessidade de discutir sua carreira pelo viés ora proposto. A presença constante e crescente de intelectuais gregos em Roma ao longo do século II a.C. despejou sobre a cidade, em um breve período, séculos de cultura acumulada: "para aqueles estudos que vocês desejam com tanto ardor não faltarão mestres" - Políbio reproduz a conversa que tivera com o jovem Cipiáo e dera início à sua proverbial amizade - "pois vejo a vasta grei de homens tais que aflui da Grécia atualmente". ${ }^{12}$ Se a cidade sofreu um processo de aculturação brusco e opressivo, o mesmo náo ocorreu com Cipiáo, cujos contatos com o mundo grego datam da casa paterna; sua formaçáo esmerada realçou por contraste a truculência que lhe foi atribuída durante os anos de maturidade, tanto na guerra quanto na política interna.

Examinar a tradição relativa a Cipião Emiliano significa examinar não apenas a sua apresentação nos textos historiográficos, mas também o diálogo mantido entre historiador e contexto, no caso de Políbio, e entre autor e fonte, no caso dos demais escritores. J. Marincola discute a ocorrência de intertextualidade na historiografia antiga como fenômeno atrelado ao que denomina "intertextualidade com a vida real". Porque as elites antigas modelavam o próprio comportamento em ancestrais reais ou imaginados, nem sempre o intertexto utilizado pelo historiador adviria de um autor específico, mas sim de um conhecimento geral dos eventos históricos. A operação não seria um problema para os antigos; ao contrário, ampliaria a credibilidade dos eventos narrados, por enquadrá-los em parâmetros discerníveis e familiares. ${ }^{13}$ Com base nessas consideraçóes, o exame dos elementos que se pretende ler como "crítica historiográfica à ânsia sem freios de honos e gloria, realizado por via da identificação das reservas mentais de Políbio e da inserção delas em referências contextuais que criticam a violência romana", permite redimensionar a imagem tradicional do historiador como agente romano que apenas endossara a política de Cipião Emiliano.

Cipiáo Emiliano nasceu (185 a.C.) em uma Roma enriquecida pelas conquistas territoriais recentes e em meio a um processo de crescimento populacional sem paralelo anterior. ${ }^{14}$ Em pouco tempo

\footnotetext{
${ }^{8}$ Plb.36.11.2.

${ }^{9} \mathrm{O}$ exemplo mais recente é BARONOWSKI, Donald Walter. Polybius and Roman imperialism, op. cit. p. 153-154.

${ }^{10}$ Ibidem, p. 174.

${ }^{11}$ GRUEN, Erich. Culture and national identity in Republican Rome. Ithaca, Nova York: Cornell University Press, 1992. p. 252-258.

${ }^{12}$ Plb.31.24.6-7.

${ }^{13}$ MARINCOLA, John. Intertextuality and exempla. Histos Working Papers, s.n., p. 5, 2011. Disponível em: <http://research.ncl.ac.uk/histos/Histos_WorkingPapers_APA_7Jan11.html>. Acesso em: 29 jan. 2013.

${ }^{14}$ HARRIS, William Vernon. The late Republic. In: SCHEIDEL, Walter; MORRIS, Ian; SALLER, Richard (Ed.). The Cambridge economic history of the Greco-Roman World. Cambridge: Cambridge University Press, 2007. p. 504 e 509: além do crescente afluxo de escravos, técnicos e artistas para Roma, entre 188 a.C. e 163 a.C. o número de cidadãos romanos adultos subiu de 258.000 para 337.000 .
} 
tornou-se herdeiro de um imenso legado material e moral. A saúde frágil privara Públio Cornélio Cipião, primogênito do Africano, de filhos e carreira política; com a morte do único irmão, também sem descendentes, Lúcio Emílio Paulo, tio materno e futuro conquistador da Macedônia, encarregou-se da fortuna, da vasta clientela e do nome do cunhado. Emílio Paulo articulou com Cipião a adoção de seu segundo filho, que daria continuidade ao legado do tio, agora avô, desde o nome: Públio Cornélio Cipião Emiliano. Antes mesmo de iniciar seus decem stipendia o adolescente já detinha a maior dignitas de seu tempo. ${ }^{15}$ Armar o próprio poder requeria ocasiōes propícias e ação.

Como qualquer aristocrata romano, Cipiáo fora meticulosamente treinado desde a adolescência a tomar decisóes rápidas e precisas, concertando leis, magistraturas e mores maiorum com a própria ambição, e evitando, quando possível, atritos com outros nobiles. A carreira militar do jovem Emiliano iniciou-se sob as ordens do próprio Emílio Paulo, na batalha de Pidna (168 a.C.), que pôs fim ao reino da Macedônia. Aos dezessete anos Cipião trará da Grécia poucas e decisivas liçóes: a alegria do pai com a vitória só foi completa quando, após horas de buscas e angústia, reconheceu o filho que retornava "saciado de sangue e carnificina, como um cão de raça embalado pelo prazer desmedido da vitória”; ${ }^{16}$ obtivera permissão paterna para caçar nos jardins reais, treinamento paramilitar de cujo entusiasmo o garoto compartilhará em Roma com seu futuro mestre, o jovem refém aqueu Políbio; para a Macedônia definitivamente submetida, Emílio Paulo "elaborou leis com tanta diligência que parecia dá-las não a inimigos vencidos, mas a benévolos aliados”; e para recompensar seus soldados, por fim, Emílio Paulo desceu ao Epiro, arrasou setenta cidades, reduziu 150 mil pessoas à escravidão, amealhou butim e redistribuiu a seus comandados. ${ }^{17}$ Nos anos seguintes a amizade com Políbio aprimorou a formação tática, intelectual e moral ${ }^{18}$ do adolescente, sobretudo por seu fundamento comum, a visão aristocrática e liberal de mundo.

No final da década de 150 a.C. recrudesceram as hostilidades na Ibéria e se acirrou a disputa territorial entre Massinissa e Cartago. Mas a pressão maior se acumulava dentro da própria Roma, com o agravamento paulatino da crise agrária. ${ }^{19}$ Foi nesse contexto, sob a incumbência de participar das tentativas de solução desses três maiores problemas, que se iniciou a carreira política de Cipiáo Emiliano. Senador aos 33 anos em 152 a.C., no ano seguinte Emiliano partiu voluntariamente para a Ibéria, como todos os seus antepassados ilustres. ${ }^{20}$ Dali passou à África para negociar com Massinissa, seu mais poderoso cliente fora de Roma, que "o saúda com grande cordialidade, pois fora amigo de seu avô". ${ }^{21}$

Esses foram também anos de apreensão para observadores externos. Entre os gregos era voz corrente que coragem e inteligência haviam forjado o império de Roma; que moderação e benevolência o am-

\footnotetext{
${ }^{15}$ O filho do Africano: Cic.Brut.77, Sen.35 e Off.1.121; o patrimônio do Africano: Plb.31.26; a adoção de Cipião Emiliano: Plut.Aem.5, Vell.1.10; árvores genealógicas dos Cornelii e dos Aemilii em WALBANK, Frank William. A historical commentary on Polybius III. Oxford: Oxford University Press, 1979. p. 504.

${ }^{16}$ Plut.Aem. 22 antecipa na sequência os dois feitos que notabilizarão o jovem; Liv.44.44.

${ }^{17}$ Emiliano, Políbio e o apreço pela caça: Plb.31.29; Cipião Emiliano patrono da Macedônia: Plb.35.4.8; Emílio Paulo impóe leis à Macedônia: Liv.45.32; aterroriza o Epiro: Plb.30.15; Liv.45.43; Plut.Aem.29. Segundo Tito Lívio, a distribuição não agradou aos soldados, que não tiveram parte no butim de Perseu; Plutarco registra a apreensão generalizada causada pelas meras onze dracmas que coube a cada um ("um povo inteiro reduzido a trocados").

${ }^{18}$ Respectivamente Plb.9.16-20 e 31.23-9.

${ }^{19}$ HARRIS, William Vernon. The late Republic, op. cit. p. 506.

${ }^{20}$ É incerto se Políbio o acompanhou: Plb.3.48.12 e WALBANK, Frank William. A historical commentary on Polybius I, op. cit. ad locum; e se Emiliano partiu como legado ou como tribuno militar: Plb.35.4.9. O pai e o tio do Africano foram mortos em combate na Ibéria em 211 a.C. e rendidos pelo jovem priuatus cum imperio: Plb.10.6-7 e Liv.25.36; em 205 a.C. o Africano fundou Italica: App.Hisp.38; Emílio Paulo exercera a pretura na Ibéria em 191 a.C.: Plut.Aem.4; Tibério Graco, pai do tribuno e sogro de Emiliano, legislou e pacificou a Ibéria, que assim permaneceu por quase vinte anos (179153 a.C.): App.Hisp.43.

${ }^{21}$ App.Pun.71-2. As tropas de Massinissa serão peças-chave para a tomada de Cartago; seu ressentimento contra os cônsules de 149 a.C., Márcio Censorino e Mânio Manílio, explica parte de suas dificuldades: App.Pun.94.
} 
pliaram; mas que desde Pidna asseguravam-no pelo terror e destruição de cidades ilustres. ${ }^{22}$ As visóes sobre a terceira fase não eram unânimes; quatro conjecturas sondavam as razóes das exigências romanas a uma Cartago já deditícia - entrega de reféns, desarmamento e recuo do sítio urbano, com toda a população, oitenta estádios $(16 \mathrm{~km})$ costa adentro, a fim de que a cidade original fosse destruída: ${ }^{23}$ alguns as aprovavam, elogiando os romanos pela defesa inteligente dos próprios interesses; outros acusavam-nos de injustamente ambiciosos; outros ainda enxergaram evidências de impiedade dolosa própria de déspotas; outros, por fim, entendiam que nada poderia ser considerado ilegal contra uma cidade que já se entregara à discrição romana. ${ }^{24}$

Havia apreensão também no Senado; era urgente um pretexto justificatório, cuja ausência postergava a guerra:

Como já estivessem decididos havia tempo, aguardavam uma ocasião que satisfizesse às próprias inclinações e um pretexto decente a olhos estrangeiros. Os romanos cuidavam disso demais, e pensavam bem: segundo Demétrio, se a origem de uma guerra tem aparência de justiça, a vitória se faz maior e o fracasso, mais seguro; se, porém, é indecorosa e ordinária, dá-se o oposto. Por isso então, divergindo quanto à opinião externa sobre si, por pouco não renunciaram à guerra. ${ }^{25}$

A guerra já estava decidida provavelmente desde 153-152 a.C., por instância sobretudo de Catão Censor, mas apenas a resistência armada de Cartago a Massinissa em 150 a.C. forneceu uma iusta causa para o cálculo romano; com a ausência de Cipião Nasica, líder da oposição a Catáo, o conflito pode ter começado já no mesmo ano. ${ }^{26}$ As dificuldades de uma campanha ultramarina eram conhecidas, porém eram premissas estabelecidas que a guerra fosse necessária, que eclodiria, e que Roma venceria; o objeto de preocupação da opiniáo majoritária era apenas qual destino dar à cidade contra a qual novamente se suscitava ódio.

A conquista de Cartago era parte de um plano maior: a cidade era uma presa rica, progressivamente enfraquecida desde Zama, e a três dias de navegação, ansiado lenitivo para uma crise socioeconômica que ameaçava a manutenção da própria nobilitas. A expectativa de imenso butim, de conquistas territoriais, de indenizaçóes pós-guerra e de prestígio militar atraiu tantos voluntários, de diversos estratos sociais, que a expedição que partia para a África continha quase quatro vezes o número das tropas oponentes. $^{27}$

\footnotetext{
${ }^{22}$ Diod. 32.2 e 4. Procedência dos fragmentos e discussão de interpretaçóes recentes cf. BARONOWSKI, Donald Walter. Polybius and Roman imperialism, op. cit. p. 106-113. Os passos derivariam de um discurso reportado por Políbio e que exporia a visão de observadores gregos; a menção à destruição de Numância (133 a.C.), cuja proveniência é incerta — se de Políbio ou de Diodoro - , não invalida a derivação polibiana nem a cronologia dos demais argumentos.

${ }^{23}$ Plb.36.7, Liv.Per.49 e App.Pun.74ss.

${ }^{24}$ Plb.36.9.3-17; discussão e interpretaçôes recentes em BARONOWSKI, Donald Walter. Polybius and Roman imperialism, op. cit. p. 101-106; MOMIGLIANO, Arnaldo. Sesto contributo alla storia degli studi classici e del mondo antico t. I, op. cit. p. 84; e CHAMPION, Craige Brian. Cultural politics in Polybius's Histories. Berkeley; Los Angeles; Londres: University of California Press, 2004. p. 196 deixam de lado as tentativas infrutíferas de identificação da opiniáo de Políbio e se concentram nos significados da apresentação — índice da enormidade do conflito e da necessária indeterminação cultural do historiador, respectivamente.

${ }^{25}$ Plb.36.2.

${ }^{26}$ Plut.Cat.Mai.26-7 e App.Pun.69. A embaixada de Catão à África para dirimir desentendimentos entre Massinissa e Cartago é de 157 a.C. Problemas de cronologia e veracidade do episódio cf. HARRIS, William Vernon. Roman expansion in the west. In: ASTIN, Alan; WALBANK, Frank William et al. (Ed.). The Cambridge ancient history v. VIII: Rome and the Mediterranean to 133 B.C. Cambridge: Cambridge University Press, 1989. p. 149-151; Cipião Nasica na Macedônia: Zon.9.28.

${ }^{27}$ Pilhagem da estátua de Apolo de mil talentos de ouro: App.Pun.127; dias de pilhagem da cidade e divisão do butim: App.Pun.133; HARRIS, William Vernon. Roman expansion in the west, op. cit. p. 152-157.
} 
Apiano descreveu os dois primeiros anos da guerra como uma sucessão de inépcias consulares contra as quais se destacavam a coragem e a perspicácia de Cipiáo Emiliano, tribuno militar que a cada dia gozava de maior admiração dos soldados. ${ }^{28} \mathrm{O}$ papel estratégico de Cipião na África se fez evidente à morte de Massinissa (148 a.C.): legatário do rei númida, Emiliano dividiu-lhe o reino e o patrimônio entre os três filhos legítimos, e renovou a aliança militar com Gulussa, com quem articulou a defecção de Himilcão Fâmeas, hiparca de Cartago. ${ }^{29}$

Cipião retornou a Roma para a eleição consular de 147 a.C. Apiano realçou o argumento da necessidade premente e o amplo respaldo da massa dos soldados, sem detalhar a meticulosa articulaçáo que quase resultou em consenso e subordinou a República à ambição de Cipião, cuja primeira obtenção do consulado deveu-se a três atos de violência institucional. Candidato à edilidade, o comício centuriado o elegeu cônsul. Tal ilegalidade apenas secundava uma primeira: Cipiáo tinha apenas 37 anos, idade insuficiente para o consulado. Os cônsules em exercício acusaram o ilícito, mas um dos tribunos da plebe ameaçou privar-lhes do ius agendi caso não acatassem a decisão dos votantes. O Senado o secundou, autorizando os tribunos a abrogar a lei por um ano. Retificadas as primeiras ilegalidades, uma terceira concluiu o processo eleitoral: Cipião submeteu ao povo a determinação das províncias, e a África lhe foi adjudicada, com a permissão de transportar "quantos soldados e voluntários conseguisse persuadir". ${ }^{30}$ Bastaria um fracasso, depois de uma manobra táo audaciosa, para abater tamanha eminência política, mas em pouco mais de um ano o novo Africano, amparado por vasto apoio popular e secundado por uma meticulosa rede de alianças políticas, terá amealhado poder e prestígio quase absolutos dentro e fora de Roma. ${ }^{31}$

A meticulosidade atribuída a Cipião Emiliano durante as operaçôes na África, da restauração da disciplina das legiôes até os seis dias e noites de pilhagens e horror, ${ }^{32}$ reproduzia na esfera militar similar habilidade estratégica que demonstrara, na política, para chegar ao consulado: planejamento cuidadoso executado na ocasiáo precisa, pleno conhecimento de todos os fatores envolvidos e consenso entre agentes empenhados por um mesmo projeto. ${ }^{33}$ A combinação coincide com a análise técnica de Políbio sobre as premissas do poder de um comandante "que age com lucidez". ${ }^{34}$ Mestre e discípulo assistiram juntos ao extermínio de uma civilização de 700 anos, conclusão lógica antevista já em 153 a.C. e corolário de uma afinidade intelectual construída ao longo de vinte anos.

O emprego deliberado de conhecimento especializado que culmina em um fim violento contrasta com o modelo não mais eficaz de resolução de conflitos adotado por Cipião e próprio da mentalidade de todas as camadas sociais que apoiaram sua eleição. Pilhar e destruir cidades, como havia muito se praticava, embora não nessa mesma escala, era mais previsível quanto a seus fins — protelar a solução de crises no interior da nobilitas - do que quanto à sua execução e, mais ainda, sua apresentação

\footnotetext{
${ }_{28}$ Provavelmente fosse Políbio a principal fonte parafraseada por Apiano: ASTIN, Alan. Scipio Aemilianus. Oxford: Clarendon Press, 1967. p. 4. Cônsules em 149 a.C.: Márcio Censorino e Mânio Manílio; em 148 a.C.: Postúmio Albino e Calpúrnio Pisão. Arrogância de Censorino: App.Pun.80-6, 97 e de Mancino (legado sob ordens de Pisão): App.Pun.113; inatividade de Censorino, Manílio e Pisão: App.Pun.94, 108, 112; incúria e imprudência de Censorino, Manílio e Mancino: App.Pun.99-102, 114.

${ }^{29}$ App.Pun.105-9.

${ }^{30}$ App.Pun.112.

${ }^{31}$ Eleição de Cipião cf. ASTIN, Alan. Scipio Aemilianus, op. cit. p. 61 e ss; Cartago foi arrasada no "início da primavera" de 146 a.C. (App.Pun.127).

${ }^{32}$ App.Pun.115-31.

${ }^{33}$ A insistência de Apiano em descrever o que havia de ilegalidade nos dois consulados de Cipião (App.Pun.112; Hisp.84; B.C.19) reforça a meticulosidade com que foi articulada a operação. Plb.38.8.7 amplia a dramaticidade do holocausto cartaginês, comparando Asdrúbal explicitamente a um boi de sacrifício.

${ }^{34}$ Plb.9.12.1. A análise de Políbio está em Plb.9.12-20; implicaçóes éticas: ECKSTEIN, Arthur. Moral vision in the Histories of Polybius. Berkeley; Los Angeles; Londres: University of California Press, 1995. p. 25-26 e 248.
} 
historiográfica. Mas a crise que demandava solução não estava restrita ao exíguo círculo da aristocracia do período; "talvez [o próprio Emiliano] tenha pensado, conforme as razóes de Cipiáo Nasica, que a destruição de Cartago fora um erro político": ${ }^{35}$ novas conquistas territoriais implicariam mais encargos militares e mais oportunidades para empreendimentos mercantis. Os primeiros gravariam ainda mais a populaçáo itálica, já à beira da exaustáo financeira, exacerbando o êxodo para Roma; as segundas ampliariam o poder de grandes associaçóes financeiras que não tardariam a pôr em xeque o da própria nobilitas.

Em suma, por sua origem em uma circunstância privilegiada; pela meticulosidade técnica e pelo lastro de violências mutuamente coniventes com que fora obtido; pelo recurso a meios ultrapassados para resolver problemas inéditos e cada vez mais complexos; pelos perigos a que expôs a República romana quando à sua testa se pôs de modo quase absoluto; e pelos precedentes que abriu ao pôr em xeque todas as instituiçôes, os quais não demoraram a ser explorados, sobretudo por seu primo e cunhado, Tibério Graco; o poder exercido por Cipião Emiliano não condizia plenamente com um modelo elogiável para um historiador como Políbio, igualmente aristocrata, oriundo de uma cidade democrática (Megalópolis) e ligado a uma linhagem política (Arato, Filopêmen, Licortas) para a qual moderação ( $\mu \varepsilon \tau \rho$ ó $\rceil \varsigma$ ) e prudência (voũs) eram virtudes cardinais para a manutenção do equilíbrio político entre distintos estados autônomos, independentemente do montante de forças de cada um.

As reaçóes em Roma à chegada da notícia e a magnificência do triunfo do novo Africano ${ }^{36}$ sugerem que o alívio de vários terrores fora, apesar de efêmero, generalizado. Prestígio; patrimônio; perícia tática; clientes em Roma, na Itália, na Sicília, na África, na Grécia, na Macedônia e na Ibéria; confiança dos soldados; apoio da plebe; liderança entre a maioria dos senadores e tribunos da plebe; ausência de opositores à altura; e o extermínio de uma civilização eram os atributos exteriores que então fizeram de Cipião Emiliano princeps rei publicae. ${ }^{37}$ Muitos anos depois, ao descrever a reação do pupilo contemplando a ruína de Cartago, Políbio fará dele o único romano a temer pela própria pátria. A apreciação sublinha o acume que espreita o imponderável do auge do sucesso, ${ }^{38}$ traça contornos ao vazio e à vertigem da ambição saciada, e adverte uma Roma mergulhada em crises sempre mais agudas. Notável nesse acume, porém, é ter se manifestado somente a posteriori.

Além das dificuldades internas e da guerra contra Cartago, desde 153 a.C. Roma enfrentava sucessivos levantes na Ibéria, também descritos como marcados por inépcias e derrotas consulares. ${ }^{39} \mathrm{~A}$ morte dos grandes políticos da década de 150 a.C. e o poder singular de Cipiáo tornaram-no alvo de frequente confrontação política nos anos seguintes, cujo pico foi a censura de 142 a.C.: longe de coroar uma carreira brilhante, teve de compartilhá-la com o desafeto plebeu Lúcio Múmio Acaico, que arrasara Corinto também em 146 a.C. ${ }^{40}$ A década de 130 a.C. se iniciou em meio a outros três graves problemas: Roma sofria com dificuldades de abastecimento a partir de 138 a.C.; o cônsul Hostílio Mancino, que

\footnotetext{
${ }^{35}$ SANCTIS, Gaetano de. Storia dei romani IV.3. Dalla battaglia di Pidna alla caduta di Numanzia. Florença: La Nuova Italia, 1964. p. 74.

${ }^{36}$ App.Pun.134-5.

${ }^{37}$ Cic. Rep.1.34.

${ }^{38}$ Plb.38.21.

${ }^{39}$ Cf. App.Hisp.45-7: 10 mil romanos mortos em 153 a.C.; \$51-3: Lúculo massacra traiçoeiramente a população de Cauca em 151 a.C.; \$59-61: o mesmo Lúculo atraiçoa também os lusitanos em 151 a.C., e Galba dá continuidade à perfídia em 150 a.C.; \$66: timidez e inexperiência de Aulo Pompeu em 143 a.C.; \$70-4: perfídia de Cepião e assassinato de Viriato em 140 a.C.; \$76-9: incúria e inatividade de Pompeu, batido pelos numantinos em 140 a.C.; \$80-3: o foedus Mancinus de 137 a.C., desânimo no Senado devido a tantos desastres, fuga vergonhosa de Emílio Lépido de Palantia, que lhe acarreta a privação do consulado em 136 a.C., inatividade de Calpúrnio Pisão em 135 a.C.

${ }^{40}$ Os grandes líderes políticos mortos foram Tibério Graco, Emílio Lépido (em 152 a.C.), Catão (em 149 a.C.) e Cláudio Marcelo (em 148 a.C.): ASTIN, Alan. Scipio Aemilianus, op. cit. p. 97; resistências políticas a Cipião Emiliano: Ibidem, p. 80s; censura e fontes: Ibidem, p. 112s; Cipião apoiado pela plebe quando eleito censor: Plut.Aem.38.
} 
por incúria caíra em uma emboscada dos numantinos, foi obrigado a se render vergonhosamente em 137 a.C.; e uma revolta de escravos eclodiu na Sicília em 136 a.C.41 .

Com duas grandes ameaças eliminadas - Cartago e o levante grego - e o Mediterrâneo sob controle, esses problemas desalentavam, sem suscitar propriamente medo. ${ }^{42}$ A guerra numantina era o mais dispendioso, financeira e psicologicamente, e demandava solução urgente: assim Apiano reportou as justificativas para o segundo consulado ilegal de Cipião Emiliano (134 a.C.). Foi o único caso de iteraçâo entre a proibição de 151 a.C. e o segundo consulado de Mário (104 a.C.), reafirmação de um poder ímpar e da intacta habilidade para explorar precedentes no momento exato. ${ }^{43}$

A descrição de seus atos na Ibéria é quase decalcada daquela da campanha contra Cartago. Cipiáo chegou à Ibéria e novamente restaurou a disciplina dos soldados com sagacidade. ${ }^{44}$ Em quinze meses os numantinos se renderam: sabendo dos riscos de uma batalha regular, Cipiáo sitiou a cidade-fortaleza com um exército mais de oito vezes superior ao dos inimigos, reduzidos ao canibalismo homicida. As cenas de horror se sucederam: Cipião decepou as mãos de quatrocentos homens de Lutia que tencionavam auxiliar os numantinos; por fim, dizimados pela fome, os poucos sobreviventes se entregaram em 133 a.C. Sua cidade também foi arrasada, mas por vontade do comandante, não por decisão senatorial, como Cartago..$^{45} \mathrm{Da}$ obtenção do segundo consulado até o fim de Numância, cada ato de Cipião parodiava seus análogos de treze anos antes. O único elemento que se exacerbava, a ponto de suscitar questionamentos de um historiador antigo, foi a crueza empregada contra os numantinos deditícios.

Ao final do relato Apiano aventou três hipóteses para explicar as decisóes de Cipião: "ou porque as julgasse do interesse dos romanos, ou porque estivesse muito irritado e propenso a vingar-se dos cativos, ou, como há quem pense, porque julgasse provir de grandes males reputaçóes notáveis". ${ }^{46}$ Ao questionar a ética do comandante subjacente à conclusão, Apiano ou sua fonte questionam indiretamente a própria guerra, que deixava poucas opçóes aos envolvidos: "há que vencer, morrer ou suportar vivo a escravidão". ${ }^{47}$ Para os romanos, a conclusão lógica de uma guerra sempre fora o extermínio; clemência e negociaçóes eram exceçôes ditadas por conveniências. Ao lado de outros exemplos de família, a violência de Cipiáo Emiliano diferiu apenas em grau da de Emílio Paulo no Epiro, ou da punição a que Cipiáo Africano submeteu a ibérica Ilúrgia em 206 a.C., cuja população fora trucidada sem distinção de sexo ou idade, e a cidade, consumida pelo fogo. ${ }^{48}$ Poucas fronteiras se manterão diante do império que alargava sob os auspícios da uirtus aristocrática, "o valor supremo em toda República, sobretudo em Roma”. ${ }^{9}$

\footnotetext{
${ }^{41}$ Discussão em ASTIN, Alan. Scipio Aemilianus, op. cit. p. 129-134.

${ }^{42}$ App. Hisp.84.

${ }^{43}$ Apiano erra ao afirmar que Emiliano não tinha a idade requerida. O problema é outro: Liv.Per.56: Cipião infringira uma lei de consulato non iterando, provavelmente de 151 a.C.; MARTINO, Francesco de. Storia della costituzione romana $t$. II. Nápoles: Eugenio Jovene, 1973. p. 422. Novamente o povo o elege cônsul, e novamente o Senado abroga uma lei. Cipião celebrará também um segundo triunfo, embora bem mais modesto do que o primeiro: Plin.33.50.

${ }^{44}$ Apiano menciona apenas Rutílio Rufo (Hisp.88), aliado político e legado de Cipião na guerra numantina, como sua fonte, mas pode ter também utilizado a monografia de Políbio mencionada por Cícero (Fam.5.12.2).

${ }^{45}$ App. Hisp.90-8.

${ }^{46}$ App.Hisp.98.

${ }^{47}$ Plb.3.63.4.

${ }^{48}$ A guerra para os romanos: MARTINO, Francesco de. Storia della costituzione romana t. II, op. cit. p. 53; Ilúrgia: Plb.11.24.10, Liv.28.20 e App.Hisp.32.

${ }^{49}$ Plb.31.29.1. MAUERSBERGER, Arno et al. Polybios-Lexikon I.1. Berlin: Akademie, 2000. p. 113 s.v. $\alpha v \delta \rho \varepsilon i ́ \alpha ~(M a n-$ nhaftigkeit); McDONNELL, Myles. Roman manliness. Virtus and the Roman republic. Nova York: Cambridge University

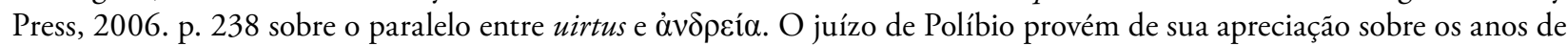
formação de Emiliano; em 152 a.C., ao oferecer-se voluntariamente para ir à Ibéria, Cipião o fazia "almejando reputação de varonia": Plb.35.4.8.
} 
Não apenas o mos maiorum respaldava as atitudes de Cipiáo Emiliano; em um passo redigido durante seus primeiros anos de detenção em Roma, correspondentes ao início da amizade com Cipiáo, Políbio fora explícito ao recomendar puniçóes exemplares e atrozes se justificadas por suas causas. ${ }^{50}$ O apreço mútuo por caça e guerra, ocupaçóes de mesma finalidade — cálculo de meios precisos para matar no momento exato —-, respaldadas pela tradição e pelas circunstâncias, forjou a mentalidade segundo a qual solucionar conflitos era questão de tática militar. Entretanto, são nítidas as ressalvas que se foram acumulando no pensamento de Políbio ao longo de quase cinco décadas de observação da política romana desde sua detenção (167-118 a.C.): a ênfase na moderação de Cipiáo Africano após Zama; ${ }^{51}$ de Emílio Paulo após Pidna; ${ }^{52}$ e de Cipiáo Emiliano após Cartago, ${ }^{53}$ quando exortou seus oficiais a jamais falar ou agir com arrogância, se prima facie enaltecia as virtudes de cada comandante, por outro lado deixava claro quanto ainda mais violentamente poderiam ter agido se o tivessem desejado, e quão questionáveis teriam sido as violências, em aparência justificadas, cometidas durante aquelas guerras. Instrução paterna, formaçáo tática e experiência acumulada rematam em um ambíguo voũs, pedra de toque do poder. ${ }^{54}$

Ao retornar da Ibéria para Roma, Cipião Emiliano foi surpreendido pela questáo gracana: pior do que um butim exíguo distribuído aos soldados, o novo problema que dominava a cena política romana anulou todas as demais vantagens que pudessem advir da tomada de Numância. ${ }^{55} \mathrm{~A}$ tensão atingiu o ápice em 129 a.C. e Cipiáo se viu no meio de duas forças tão antagônicas quanto devastadoras: incapaz de equalizar as pressóes exercidas por sua clientela itálica, hostil à proposta do tribuno, e pela plebe urbana, que o secundara em todas as suas iniciativas políticas e ansiava pela reforma agrária, foi encontrado morto em circunstâncias que já eram misteriosas aos próprios contemporâneos. Na última frase que Plutarco lhe atribuiu, fica clara a percepção, por parte do próprio Cipião, de sua inadequação aos novos tempos. À multidão pró-gracanos que gritava "morte ao tirano!" respondeu: "é natural que os que guerreiam contra a própria pátria queiram me destruir. Não é possível que Roma caia enquanto Cipiáo estiver de pé, nem que Cipião continue vivo após a queda de Roma”. ${ }^{56}$ Pagou com a vida a incapacidade de propor novas soluçóes para conflitos mais complexos.

A imagem plausível de um homem que conviveu cotidiana e longamente com intelectuais do calibre de Catâo, Políbio, Panécio e Lucílio — os nomes mais conhecidos — agrava por contraste as implicações éticas negativas decorrentes da meticulosidade e truculência atribuídas a Cipião no trato com os adversários políticos e inimigos de guerra. Convivência com intelectuais, no caso de Cipiáo, significou sobretudo aquisição de reputação pessoal para posterior triunfo político; a maior contribuição do helenismo para sua formação e carreira foi a especialização tática e estratégica. Políbio reitera que o discípulo se esforçou para alcançar a fama $(\delta o ́ \xi \alpha)$, não necessariamente as virtudes, de continência, temperança, excelência e coragem, ${ }^{57}$ e foi precisamente após e em razão da longa convivência consigo que Cipião realizou os feitos que o notabilizaram. A escala de violências atribuídas a Cipiáo contra

\footnotetext{
${ }^{50}$ Cf. os episódios envolvendo a cidade de Mantineia e o tirano de Argos Aristômaco em Plb.2.56-61, especialmente os juízos de \$58.11: “[os mantineus] mereciam punição maior e absoluta” e $\$ 60.7$ : “[Aristômaco] deveria ter sido arrastado pelo Peloponeso e morrido servindo de punição exemplar”. Eventuais motivaçóes políticas de Políbio: WALBANK, Frank William. A historical commentary on Polybius I, op. cit. ad locos.

${ }^{51}$ Plb.15.17.3-18.8.

52 Plb.29.20.

${ }^{53}$ Plb.38.20.1-3.

${ }^{54}$ Noṽ $\varsigma$ - lucidez — é a faculdade suprema de um comandante para Políbio: 9.12.1; resulta do concerto entre $\pi \rho o ́ v o t \alpha$

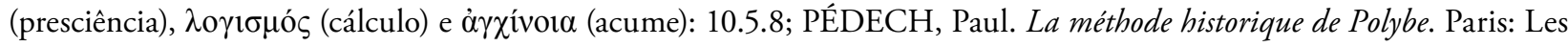
Belles Lettres, 1964. p. 210-211.

${ }^{55}$ ASTIN, Alan. Scipio Aemilianus, op. cit. p. 231.

56 Plut.Reg.Imp.Apoph.201f.

${ }^{57}$ Plb.31.25.8; 31.28.10; 31.29.9.
} 
adversários políticos e inimigos externos ultrapassou com folga a de seus ancestrais e a dos homens que Políbio criticara como exemplos máximos de análoga falta de $\mu \varepsilon \tau \rho ı ́$ $\eta \varsigma$, quais Cleômenes de Esparta e Perseu da Macedônia. ${ }^{58}$ A situação de subordinação política levou Políbio a, sob os elogios protocolares, costurar cuidadosamente uma rede de topoi ambivalentes, criticando a violência empregada pela potência dominante, com Cipião à testa, para resolver sobretudo conflitos externos. Um tipo de ironia caro a quem, em função dos relacionamentos que mantinha com a elite romana e pressionado pela necessidade de construir uma narrativa verossímil, teve de recorrer ao contraste entre sutis reservas mentais e os contextos em que criticara atitudes violentas para sinalizar os próprios motivos de preocupação. Ao reportar tais passos, Apiano, Plutarco e Diodoro preservaram juízos que podem remontar a Políbio.

A identificação de intertextualidade é "um convite à interpretação, e não o seu fim". 59 A imagem que emerge da tradição iniciada com Políbio, sobre o historiador e seu discípulo, é duplamente ambivalente e evidencia a delicada relação entre ambos. De um lado, Políbio se apresenta como mestre afeiçoado, embora dificilmente pudesse justificar, aos olhos dos gregos seus contemporâneos, qualquer endosso da violência de Cipião e de outras análogas, como a destruição de Corinto por Lúcio Múmio, ocorrida no mesmo ano do excídio de Cartago: o que o distinguiria do odiado Calícrates, que se cooptara com os romanos para aniquilar adversários políticos dentro da Liga Aqueia, atitude diretamente responsável pela detenção do próprio Políbio e de mais mil outros reféns? De outro lado, Cipião é apresentado como um dos expoentes máximos da uirtus aristocrática, posição evidenciada pelo poder e prestígio sem paralelos que adquirira, ultrapassando a gloria dos próprios ancestrais, dentre as maiores até então obtidas; mas o valor positivo que isso tinha em Roma não correspondia a uma mesma percepçáo por parte da aristocracia grega mantida no poder em situação de clientela, e por isso duplamente intranquila, pela perene ameaça de intervenção romana violenta em caso de dissidências, e pela permanente aura de suspeita em que se via envolvida aos olhos de contemporâneos dispostos a rebelar-se contra o domínio estrangeiro, seguindo os passos de Dieu e Critolau.

O poderio acumulado por Roma, como o análogo poderio de Cipião Emiliano, despertava no mínimo preocupação por parte dos gregos após 146 a.C., fenômeno que pode ser rastreado nas reservas mentais de Políbio em relação ao expansionismo romano e aos atos do discípulo: dividido entre a gratidão por sua condição privilegiada em Roma quando refém e a preocupação ante a instabilidade inerente à própria situação ${ }^{60}$ após 146 a.C.; e forçado a escrever para uma dupla audiência com pontos de vista antagônicos, o historiador opta por mesclar a descrição dos expedientes romanos a juízos que os questionassem, como as quatro opinióes correntes entre os gregos após as exigências romanas a Cartago em 150-149 a.C. e as três hipóteses reportadas por Apiano para explicar as decisóes de Cipiáo contra Numância.

D. Baronowski define suas conclusóes como um "protesto contra o injusto veredito" de G. de Sanctis, que definira Políbio como traidor por ter sacrificado sua integridade intelectual. ${ }^{61}$ Essas conclusôes carecem, porém, de uma importante qualificação: se não há elementos suficientes para definir Políbio como traidor, é igualmente impossível provar que não o fora. A questão é outra: mais interessante e promissor é perceber a relação entre os diversos elementos encadeados em seu texto e na tradição que

\footnotetext{
${ }^{58}$ Cleômenes: Plb.2.61.4; Perseu: Plb.27.8.4.

${ }^{59}$ MARINCOLA, John. Intertextuality and exempla. Histos Working Papers, s.n., p. 3, 2011. Disponível em: <http://research.ncl.ac.uk/histos/Histos_WorkingPapers_APA_7Jan11.html>. Acesso em: 29 jan. 2013.

${ }^{60}$ No epílogo das Histórias Políbio redige uma pequena prece que, embora tópica, é indício de sua situação: "pedimos a todos os deuses que aquilo que nos resta ainda para viver possa continuar nas mesmas condiçóes; vemos quanto o acaso aprecia invejar os homens e como é mais incisivo no momento em que alguém mais se crê feliz e bem-sucedido na vida" (Plb.39.9.2).

${ }^{61}$ BARONOWSKI, Donald Walter. Polybius and Roman imperialism, op. cit. p. 174: "the present study, which builds on the foundations of earlier scholarship, may be taken as a protest against this unjust verdict".
} 
dele depende, e as ambivalências inerentes ao período, ao homem e aos seus juízos. Embora todos esses problemas possam ser notados ao longo de todo o texto das Histórias, os passos da narrativa que tratam da carreira de Cipião Emiliano e da Terceira Guerra Púnica, e seus ecos na tradição subsequente, formam os loci privilegiados para discutir tais ambivalências.

A principal implicação da condição ambivalente de Políbio após 167 a.C. - era um aristocrata grego detido em Roma sem julgamento, um jovem estrategista que só tinha permissão para observar

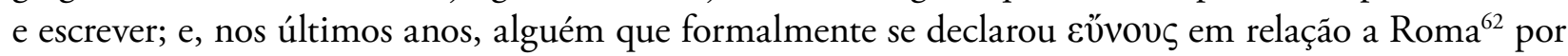
discordar das iniciativas de Dieu e Critolau que acarretaram a Guerra Acaica - , a qual projeta nova luz sobre o entendimento de sua obra, reside na própria ambiguidade inerente à decisão de investigar como o poderio romano se originou e operava. ${ }^{63}$ A mesma ambiguidade marca, por exemplo, sua decisão de inserir um excurso que explicasse a origem da amizade com Cipião Emiliano, decisão que também mostra que Políbio tinha total consciência de quantas diferenças o separavam do discípulo. ${ }^{64}$ Narrar a Terceira Guerra Púnica e a carreira do discípulo foi um expediente que poupou sua vida e justificou seus vínculos com o poderio romano; ao mesmo tempo, mas por outro lado, o mesmo expediente poderia ser lido pela elite grega sua contemporânea como uma sutil advertência, sobretudo após 146 a.C.: que aceitasse resignada a supremacia romana ou, caso decidisse restaurar algo da autonomia anterior a 167 a.C., que meditasse cuidadosamente sobre como agir, principalmente para não atrair mais uma vez para solo grego uma máquina militar de tamanha eficiência. Se Políbio esteve longe de ser um revolucionário, não foi tampouco propriamente um conformista. Identificar, conforme possível, os percursos de seu pensamento a partir de sua própria obra, ou da tradição que preservou algo de seus juízos, ainda é mais importante do que qualquer tentativa de encontrar o melhor rótulo que lhe caiba. Por consequência, o mesmo vale para os significados dos objetos de sua narrativa.

\footnotetext{
${ }^{62}$ Plb.39.8.2.

${ }^{63}$ CHAMPION, Craige Brian. Cultural politics in Polybius's Histories, op. cit. p. 196-197.

${ }^{64}$ Dito explicitamente em Plb.31.24.11.
} 